\title{
KAJIAN YURIDIS TENTANG PENGELOLAAN TANAH PENGUASAAN PEMERINTAH KOTA MALANG YANG DISEWA OLEH PIHAK KETIGA
}

\author{
R. Moeljono, Imam Koeswahyono, Aan Eko Widiarto, Sutoyo \\ dan Darin M. Mualiffien ${ }^{1}$
}

\begin{abstract}
This paper is the result of the study the research team on the ground with the city government control study in Malang, as was the case in ex-or former Gemeente areas such as Jakarta, Bandung, Medan, Surabaya, Malang, Manado, Palembang, Makassar, Pasuruan, shows historical or history of land tenure municipal government are manifold can occur because of a statutory provision, purchasing or procurement tanahuntuk public interest, the submission of other authorized parties, including also because of changes in the status of the village that turned into the Village. Most of the City Government has yet to implement provisions of law relating to land especially land tenure that city government should have clung to the Rights Management, but until now there has been dilaksakan, so it does not guarantee the certainty of the rights and the rule of law. Necessary efforts seriously and continuing to conduct data collection, inventory and periodic recording of local government assets, in coordination with relevant stakeholders such as the National Land Agency, Tax Office Primary.
\end{abstract}

Keywords: management, land tenure, the city, rent

\begin{abstract}
Abstrak
Tulisan ini merupakan hasil kajian tim peneliti mengenai tanah penguasaan pemerintah kota dengan studi di Kota Malang, seperti halnya yang terjadi di eks atau bekas daerah Gemeente seperti: DKI, Bandung, Medan, Surabaya, Malang, Manado, Palembang, Makassar, Pasuruan, menunjukkan secara historis atau riwayat perolehan tanah penguasaan pemerintah Kota banyak ragamnya bisa terjadi karena ketentuan undang-undang, pembelian atau pengadaan tanahuntuk kepentingan umum, penyerahan dari pihak lain yang sah, termasuk pula karena adanya perubahan status Desa yang berubah menjadi Kelurahan. Sebagian besar Pemerintah Kota belum melaksanakan ketentuan peraturan hukum tanah khususnya yang berkaitan dengan tanah-tanah penguasaan pemerintah Kota yang seharusnya dilekati dengan Hak Pengelolaan, tetapi hingga saat ini belum dilaksakan, sehingga tidak terjamin adanya kepastian hak dan kepastian hukumnya. Diperlukan upaya secara sungguh-sungguh dan berkelanjutan untuk melakukan pendataan, inventarisasi serta pencatatan secara periodik aset
\end{abstract}

1 R. Moeljono, Imam Koeswahyono, Dosen Hukum Agraria FH-Unibraw, Aan Eko Widiarto, Sutoyo, Dosen Pendidikan Hukum Univ.Negeri Malang, Darin M. Mualiffien, Dosen Univ.Islam Kadiri, di Kediri. Alamat kontak: imam_koeswahyono@yahoo.com. 
pemerintah daerah, dengan berkoordinasi dengan pemangku kepentingan yang terkait seperti Badan pertanahan Nasional, Kantor Pelayanan Pajak Pratama.

Kata kunci: pengelolaan, tanah penguasaan, pemerintah kota, sewa

\section{Latar Belakang}

Kebutuhan orang akan tanah terutama di daerah perkotaan terus meningkat seiring dengan jumlah pertambahan penduduk baik secara alami maupun karena adanya urbanisasi.

Sebagaimana diketahui bahwa rumah adalah bangunan yang berfungsi sebagai tempat tinggal atau hunian dan sarana pembinaan keluarga, adalah merupakan kebutuhan dasar manusia yang perlu dan terus ditingkatkan pemerataan dan kesejahteraannya.

Untuk memenuhi kebutuhan akan tanah guna keperluan tempat tinggal, peran Pemerintah/Pemerintah Daerah sangat menentukan seperti melalui hubungan hukum dan/atau perbuatan hukum antara pemerintah daerah dengan masyarakat yang sangat membutuhkannya, sebagaimana implementasi ketentuan pasal 2 ayat (2) UUPA.

Sebagaimana yang dilakukan oleh Pemerintah Kota Malang, bahwa beberapa wilayah di kota Malang terdapat tanah penguasaan pemerintah Kota Malang yang disewa oleh Pihak Ketiga yang implementasinya diatur dalam PERDA Nomor: 4 tahun 1997 tentang Penggunaan Tempat-tempat Tertentu.

Untuk mengetahui dan memahami bagaimana cara pengelolaan tanah penguasaan dimaksud, hal ini tidak terlepas dari proses perolehan, pemanfaatan, pengamanan dan cara pelepasan tanah penguasaan tersebut.

Sebagaimana diketahui bahwa berkaitan dengan perolehan, pemanfaatan, pengamanan serta cara pelepasan tanah penguasaan pemerintah Kota Malang yang disewa oleh Pihak Ketiga, terdapat di dalam berbagai peraturan perundangundangan.

Adapun beberapa ketentuan peraturan perundang-undangan yang berkaitan dengan perolehan barang milik daerah sebagai petunjuk dapat diketengahkan sebagai berikut:

Pasal 2 PP. No. 38 Tahun 2008

(1) Barang Milik negara/daerah meliputi:

a. Barang yang dibeli atau diperoleh atas beban APBN / APBD atau

b. barang yang berasal dari perolehan lainnya yang sah;

(2) Barang sebagaimana dimaksud pada ayat (1) huruf b. meliputi:

a. barang yang diperoleh dari hibah/sumbangan atau yang sejenis; 
b. barang yang diperoleh sebagai pelaksanaan dari perjanjian/ kontrak;

c. barang yang diperoleh berdasarkan ketentuan undangundang; atau

d. barang yang diperoleh berdasarkan putusan pengadilan yang telah memperolehkekuatan hukum tetap.

Sedangkan yang terkait dengan pemanfaatan, pengamanan dan pelepasan terhadap barang milik daerah diatur dalam Peraturan Menteri Dalam Negeri No. 17 Tahun 2007 antara lain menyebutkan:

\section{Pasal 1 angka 18}

Pemanfaatan adalah pendayagunaan barang milik daerah yang tidak dipergunakan sesuai dengan tugas pokok dan fungsi Satuan Kerja Perangkat Daerah (SKPD) dalam bentuk sewa, pinjam pakai, kerjasama pemanfaatan, bangun guna serah dan bangun serah guna dengan tidak mengubah status kepemilikan.

\section{Pasal 1 angka 16}

Pengamanan adalah kegiatan tindakan pengendalian dalam pengurusan barang milik daerah dalam bentuk fisik, administratif dan tindakan upaya hukum.

\section{Pasal 1 angka 19}

Sewa adalah pemanfaatan barang milik daerah oleh pihak lain dalam jangka waktu tertentu dengan menerima imbalan uang tunai.

\section{Pasal 1 angka 24}

Penghapusan adalah tindakan menghapus barang milik daerah dari daftar barang dengan menerbitkan surat keputusan dari pejabat yang berwenang untuk membebaskan pengguna dan/atau kuasa pengguna dan/atau pengelola dari tanggung jawab administrasi dan fisik atas barang yang berada dalam penguasaannya.

\section{Pasal 1 angka 26}

Penjualan adalah pengalihan kepemilikan barang milik daerah kepada pihak lain dengan menerima penggantian dalam bentuk uang.

Memperhatikan ketentuan peraturan perundang-undangan tersebut di atas apabila dihubungkan dengan ketentuan UU. No. 5 Tahun 1960 tentang Peraturan Dasar Pokok-Pokok Agraria terdapat perbedaan konsep dan penafsiran. 
Sebagai contoh tentang pengertian Hak Sewa, Pemanfaatan dan Pelepasan Hak adalah sebagai berikut:

\section{Pasal 44 UUPA Hak Sewa menyatakan}

(1) Seseorang atau suatu badan hukum mempunyai hak sewa atas tanah, apabila ia berhak mempergunakan tanah-milik orang lain untuk keperluan bangunan, dengan membayar kepada pemiliknya sejumlah uang sebagi sewa.

Pasal 1 angka 4 PP. No.16 Tahun 2004

Pemanfaatan tanah adalah kegiatan untuk mendapatkan nilai tambah tanpa mengubah wujud fisik penggunaan tanahnya.

Keputusan Menteri Negara Agraria/Kepala BPN No. 21 Tahun 1994 (Pasal 1 angka 4)

Penyerahan atau pelepasan hak adalah kegiatan melepaskan hubungan hukum antara pemegang hak atas tanah dengan tanah yang dikuasainya dengan pemberian ganti kerugian atas dasar musayawarah.

Selanjutnya berkaitan dengan riwayat perolehan tanah penguasaan pemerintah Kota Malang adalah sebagai berikut:

1. Barang yang dibeli atau diperoleh atas beban APBN/APBD atau

2. barang yang berasal dari perolehan lainnya yang sah; dan

3. barang yang diperoleh berdasarkan ketentuan undang-undang;

Sebagaimana diketahui bahwa riwayat perolehan tanah penguasaan pemerintah Kota Malang tidak dapat dipisahkan dengan sejarah Kota Malang periode sebelumnya, yaitu pada masa pemerintah penjajahan Belanda yang disebut dengan Staat Gemeente (Kotapraja).

Mengutip dari Respati Wikantiyoso, bahwa HUT resmi Kota Malang diambil dari tanggal 1 April 1914 dimana pada tanggal tersebut bertepatan dengan ditentukannya kota Malang sebagai Gemeente (Kotapraja) Malang. ${ }^{2}$

2 Sesungguhnya Belanda mulai masuk ke Malang sejak tahun 1767 dengan mendirikan benteng di daerah yang sekarang ditempati Rumah sakit Syaiful Anwar di daerah Kojen Lor. Di dalam benteng tersebut didirikan pemukiman awal Belanda. Kata Klojen berasal dari kata " loji" yang berarti sebutan untuk rumah orang Belanda, dari kata tersebut berkembang menjadi "ke-lojian dan akhirnya menjadi Klojen.

Di daerah itu dahulu juga terdapat makam Belanda, tetapi kemudian dipindah ke daerah Sukun pada saat rencana pengembangan kota (bouwplan) tahap ketiga, sekitar tahun 1920 .

Disamping makam Belanda yang sudah ada pada waktu itu kemudian pada tahun 1920 dibangun lagi makam Belanda di Sukun. Selanjutnya pada tahun 1821 Belanda memantapkan 
Dari paparan tersebut di atas dapat dipahami bahwa persewaan tanah oleh pemerintah Staat Gemeente pada waktu itu mendasarkan pada ketentuan pasalpasal yang ada pada Burgerlijk Wetboek sebagai awal dari adanya perjanjian sewa-menyewa tanah penguasaan Pemerintah Kota Malang yang ada pada saat ini.

Pada masa pemerintahan Staat Gemeente terdapat suatu perusahaan yang disebut Grondbedrijf atau perusahaan tanah, yang disewakan kepada masayarakat yang membutuhkannya.

Dari uraian tersebut di atas, dapat difahami bahwa tanah-tanah yang dibebaskan dari penduduk tersebut diajukan permohonan Hak Eigendom atas nama Pemerintah Gemeente, tetapi permohonan hak Eigendom tersebut belum semuanya dapat terselesaikan karena adanya peperangan antara pemerintah Belanda dengan tentara Jepang. Lokasi tanah persewaan/Grondbedrijf ini dapat perkirakan pada daerah-daerah yang strategis seperti daerah jalan Pulau-pulau, dan di beberapa daerah juga terdapat tanah-tanah Eigendom tertulis atas nama Staat Gemeente (Kotapraja) Malang.

Selanjutnya setelah kemerdekaan RI, pengaturan tanah-tanah yang dahulu dimiliki oleh pemerintahan Staat Gemeente, sampai pada masa penjajahan Jepang

kedudukannya di Malang dan mulai meluaskan permukiman keluar benteng, di beberapa tempat didirikan bangunan militer untuk mengamankan daerah-daerah tersebut.

Pada sekitar tahun 1824 Pemerintah Belanda menetapkan wilayah Malang menjadi Karesidenan bersamaan dengan itu kemudian dibangunlah kantor-kantor pemerintah dan daerah permukiman untuk pegawai-pegawai pemerintah di daerah Alun-alun, Terminal Patimura, dan sekitarnya.

Perkembangan selanjutnya dilakukan pembagian zona yaitu : Zona I disebut Bergenbuurt (kawasan yang menggunakan nama Jalan Gunung-gunung) meliputiperumahan tipe besar dan jenis Villa. Zona II disebut Orangebuurt (kawasan yang menggunakan nama Jalan pahlawan-pahlawan) untuk perdagangan, jasa dan pusat pemerintahan baru. Zona III disebut Eilandenbuurt, kawasan yang sekarang menggunakan nama Jalan Pulau-pulau untuk perumahan kelas menengah ke bawah dan daerah industri.

Kota Malang yang dahulu merupakan Staadgemeente juga menguasai tanah-tanah yang berstatus Hak Eigendom dan ada pula yang berstatus vriylands domein (tanah negara), karena pada saat pembeliannya belum sempat diajukan permohonan balik nama. Peruntukan dan penggunaan tanah tersebut sebagian untuk Gedung dan lapangan Olah Raga dan/atau Stadion, Kantor-kantor Pemerintah, fasilitas Umum seperti taman kota, jembatan, tempat pemakaman dan sebagian lagi untuk perusahaan tanah (Grondbedrijf).

Pada zona III inilah tampaknya embrio lokasi tanah-tanah persewaan kota Malang, yang pada masa pemerintah Gemeente dibentuk suatu lembaga Grondbedrijf/ perusahaan tanah.

Pada tanggal 16 Mei 1878 dibuka jalur kereta api Surabaya- Malang dan Pasuruan, pembukaan jalur ini menyebabkan perkembangan kota Malang menjadi semakin pesat, antara bagian selatan kota, yaitu Kotalama dihubungkan dengan jalur tram ke utara yaitu Blimbing.

Pada tahun 1882 Belanda melakukan pembangunan perumahan di barat Brantas dan membuat alun-alun. Perkembangan selanjutnya adalah adanya pembangunan daerah perumahan berdasarkan kelompok etnis (sekitar tahun 1914) yaitu sebagai berikut :

a.Daerah permukiman Pribumi (kurang lebih 40.000 jiwa) di sebelah selatan alun-alun, Kebalen, Temanggungan, Talun, Klojen Lor dan Jodipan.

b.Daerah permukiman bangsa Eropa (kurang lebih 2.500 jiwa) di sebelah barat daya alunalun, Kayutangan, Oro-oro Dowo, Celaket, Klojen Lor dan Rampal.

c. Daerah permukiman Cina di sebelah timur alun-alun, dikenal sebagai daerah "Pecinan" . 
tidak terurus, demikian pula banyak surat-surat atau dokumen Kantor yang tidak tersimpan dengan baik, sehingga untuk mendapatkan riwayat tanah tersebut secara kronologis sulit untuk dilacak.

Kemudian di dalam perkembangannya bahwa tanah penguasaan pemerintah kota Malang adalah diperoleh atas beban Anggaran Pendapatan Daerah (APBD), yaitu melalui cara pembelian/pembebasan tanah dan ada pula tanah penguasaan yang berasal dari perolehan lainnya yang sah, sebagai contoh tanah Negara bekas rail ban lori penguasaan PG. Kebon Agung yang pada waktu itu diserahkan kepada Pemerintah Kotamadya Malang yang dahulu diatur dalam UU No.18 Tahun 1965.

Disamping itu, terdapat pula tanah penguasaan pemerintah kota Malang yang berasal karena adanya perubahan wilayah Desa menjadi Kelurahan, sehingga tanah ex Bengkok Desa yang berubah menjadi kelurahan tanah-tanah tersebut menjadi tanah penguasaan pemerintah Kota Malang, sebagaimana diatur dalam Peraturan Menteri Dalam Negeri Nomor: 1 tahun 1982 tentang Tanah Kas Desa.

Berdasarkan data yang diperoleh penulis bahwa lokasi tanah yang termasuk tanah penguasaan pemerintah kota Malang tersebut meliputi:

\section{Sebagian Kompleks Jalan Bunga-Bunga yaitu:}

J1. Bungur, J1. Melati, J1 Anggrek, J1. Sruni, J1 Kenongo, J1 Bungur, J1. Menur, Jl. Sedap Malam, Jl Pudak, Jl. Semboja, Jl. Pacar dan lain-lain.

Disamping itu terdapat pula tanah-tanah Jl. Kompleks Bunga-Bunga yang tidak termasuk tanah penguasaan Pemerintah Kota Malanag, tetapi berasal dari pengaplingan tanh Hak Yasan yang dilakukan oleh perorangan / badan hukum seperti di J1. Lely, Jl. Flamboyan, J1. Truly, J1. Anggrak Garuda dan lain-lain.

\section{Sebagian Kompleks Jalan Kali-Kali}

Sedangkan tanah penguasaan pemerintah Kotamadya Malang yang dahulu sebagian di bangun oleh YKP dan sebagian dibangun oleh perorangan, terletak di J1. Kali-Kali antara lain yaitu :

Jl. Serayu, Jl. Bango, J1. Lahor, J1. Sampeyan dan lain-lain.

Demikian pula terdapat tanah-tanah perumahan yang berada di Kompleks J1. Kali-Kali tetapi tidak termasuk tanah penguasaan Pemerintah Kota Malang yang berasal dari pengaplingan atas tanah Negara seperti tanah-tanah yang terletak di komplex Jl. Mahakam.

\section{Sebagian Kompleks Jalan Buah-Buahan}

Tanah-tanah penguasaan pemerintah Kotamdya Malang yang dahulu dibangun oleh YKP dan sebagian tanah kososng yang disewa oleh Pihak Ketiga terletak antara lain di Jl. Rambutan, Taman Gayam, Juwet, Jambu dan lain-lain.

\section{Sebagian Kompleks Jalan Pulau-Pulau}

Demikian pula sebagian tanah-tanah yang dibangun oleh YKP dan sebagian berupa tanah kosong yang disewa oleh Pihak Ketiga terletak antara lain di Jl. Mentawai, Taman Riau, Siberut dan lain-lain. 


\section{Sebagian Kompleks Jalan Burung-Burung}

Misalnya Jalan, Beo, Jalan Cucak rawa, dan lain-lain.

\section{Sebagian Kompleks Jalan Gunung-gunung baru}

Seperti jalan taman agung, j1 bukiut barisan, puncak jaya, dll.

Apabila diperhatikan secara seksama bahwa tanah penguasaan pemerintah Kota Malang yang disewa oleh Pihak Ketiga tersebut masih belum jelas statusnya, sehingga menimbulkan tidak adanya kepastian hak dan kepastian hukum.

Bahwa tanah-tanah penguasaan pemerintah Kota Malang yang semula disewa oleh pihak Ketiga peruntukan dan penggunaannya untuk keperluan rumah tempat tinggal, tetapi dalam perkembangannya telah dimanfaatkan untuk berbagai kepperluan seperti untuk usaha perdagangan, industri, jasa dan lain-lain.

Adapun dasar hukum yang melandasi perjanjian sewa-menyewa antara pemerintah Kota Malang dengan Pihak Ketiga tersebut antara lain dapat diketemukan beberapa produk hukum sebagai berikut :

1) Dewan Pemerintah Daerah Kota Besar Malang, berdasarkan Pasal 35 UU. No. 22 Tahun 1948 dengan memperhatikan Keputusan Dewan Perwakilan Rakyat Daerah Sementara tanggal 31 Mei 1951 No. 27/D.P.R. dan dan Keputusan Dewan Pemerintah Daerah tanggal 5-81954 No. 477/Pku .........dst.

2) seterusnya, dilakukan PERJANJIAN SEWA-MENYEWA antara DEWAN PEMERINTAH KOTA BESAR MALANG dengan AM Lokasi tanah di Jalan Tawang Mangu Malang.

3) Walikota Kepala Daerah Malang, yang dalam hal ini berdasarkan pasal 14 (3) Penetapan Presiden Republik Indonesia No. 6/1959 bertindak untuk dan atas nama Kotapraja Malang dengan memperhatikan Keputusan Dewan Perwakilan Rakyat Daerah Sementara tanggal 30-91961 No. 1519/KD/61 selanjutnya.......... dan seterusnya dilakukan PERJANJIAN SEWA-MENYEWA antara WALIKOTA KEPALA DAERAH MALANG dengan SM lokasi tanah di Rencana Lingkungan Pembangunan VII Jalan .......... Desa/LingkunganPurwodadi, Kecamatan Koljen dalam Kotapraja Malang. (Catatan dalam peta Komplex Buah-buahan Jl. Kawista).

Bentuk-bentuk produk hukum yang menjadi dasar perjanjian sewamenyewa tersebut masih banyak ragamnya, selanjutnya akan ditampilkan pula produk hukum yang dipakai dasar untuk PELEPASAN HAK atas tanah yang disewa oleh Pihak Ketiga sebagai berikut:

\section{Reg. No.21/1955}

\section{PERJANJIAN JUAL- BELI DI BAWAH TANGAN} DEWAN PEMERINTAH DAERAH BKOTA BESAR MALANG, ---

Yang dalam hal ini bertindak untuk dan atas nama Kota Besar Malang berdasarkan keputusan Dewan Perwakilan Rakyat Daerah Sementara Kota Besar Malang tanggal 22 Juni 1955 No. 27/DPR 
selaanjutnya disebut fihak kesatu, mengakui telah memindahkan hak pertama atas sebidang tanah kepada:

W_bertempat tinggal di jalan Menari No. 15 Malang ....... dan seterusnya.

Selanjutnya mengenai persewaan tanah yang dilakukan oleh pemerintah kota Malang kepada Pihak Ketiga diatur dengan suatu Keputusan Walikotamadya Kepala Daerah kemudian diatur dengan Peraturan Daerah No. 4 Tahun 1997 tentang Pemakaian Tempat-tempat tertentu yang dikuasai oleh Pemerintah Daerah.

Perkembangan selanjutnya dengan diundangkannya UU. No.5 Tahun 1960 tentang Peraturan Dasar Pokok-Pokok Agraria (UUPA) atau dalam arti sempit dikeluarkannya ketentuan Hukum Tanah, maka segala ketentuan yang berkaitan dengan persoalan tanah harus mengacu pada UUPA. Sebagaimana dikemukakan oleh Boedi Harsono:

Semua hak penguasaan atas tanah berisi serangkaian wewenang, kewajiban, dan/atau larangan bagi pemegang haknya untuk berbuat sesuatu mengenai tanah yang dihaki. "Sesuatu" yang boleh, wajib atau dilarang untuk berbuat, yang merupakan isi Hak Penguasaan Atas itulah yang menjadi kriterium atau tolok pembeda di antara hakhak penguasaan atas tanah dalam Hukum Tanah. ${ }^{3}$

Bahwa wewenang kewajiban dan larangan yang berhubungan dengan Hak Penguasaan Atas Tanah tersebut meliputi:
a. Kewenangan Privat
b. Kewenangan Publik
c. Kewenangan privat dan sekaligus kewenangan publik.

Terkait dengan pengertian hak atas tanah dapat kita temukan jenis hak-hak atas tanah sebagaimana tercantum di dalam Pasal 16 yaitu:
a) Hak Milik;
b) Hak Guna Usaha;
c) Hak Guna Bangunan;
d) Hak Pakai;
e) Hak Sewa;
f) Hak membuka Tanah;
g) Hak memungut hasil hutan dan
h). Hak-hak lain yang tidak termasuk dalam hak-hak tersebut di atas yang akan ditetapkan dengan undang-undang serta hak-hak yang sifatnya sementara sebagai yang disebutkan dalam pasal 53.

Selain hak-hak atas tanah tersebut diatas kita kenal pula Hak Pengelolaan. Istilah hak pengelolaan ini tidak kita ketemukan di dalam jenis hak-hak atas tanah

\footnotetext{
${ }^{3}$ Boedi Harsono, Hukum Agraria Indonesia Bagian Pertama, sejarah penyusunan Isi dan Pelaksanaannya, Djambatan Jakarta, 1978, hal. 23-24.
} 
yang ada di dalam pasal 16 UUPA, tetapi dapat kita ketemukan istilah pengelolaan dalam Penjelasa Umum UUPA angka II (2) alinea terakhir menjelaskan sebagai berikut:

Kekuasaan Negara atas tanah yang tidak dipunyai dengan sesuatu hak oleh seseorang atau pihak lainnya adalah lebih luas dan penuh.

Dengan berpedoman pada tujuan yang disebutkan di atas (tujuan untuk mencapai sebesar-besar kemakmuran rakyat) Negara dapat memberikan tanah yang demikian itu dan kepada seseorang atau badan-badan hukum dengan sesuatu hak menurut peruntukan dan keperluannya misalnya hak milik, hak guna usaha, hak guna bangunan atau hak pakai atau memberikannya dalam pengelolaan kepada suatu Badan Usaha (Departemen, Jawatan atau Daerah Swatantra) untuk dipergunakan bagi pelaksanaan tugasnya masing-masing (Pasal 2 ayat 4).

Dari rumusan tersebut di atas bahwa untuk Departemen, Jawatan atau Daerah Swatantra tidak dapat diberikan tanah dengan status hak milik, dengan demikian apabila tanah yang dikuasai oleh Departemen, Jawatan atau Daerah Swatantra akan diberikan kepada Pihak Ketiga, maka tanah tersebut harus berstatus Hak Pengelolaan.

Sesuai dengan ketentuan Peraturan Menteri Agraria No. 9 Tahun 1965 menyebutkan:

Dengan mengubah seperlunya ketentuan dalam Peraturan Menteri Agraria No.9 Tahun 1965 tentang "Pelaksanaan Konversi Hak Penguasaan atas Tanah Negara dan Ketentuan - Ketentuan tentang Kebijaksanaan Selanjutnya" di dalamnya mengatur mengenai wewenang pemegang hak pengelolaan yaitu:
a. merencanakan peruntukan dan penggunaan tanah yang bersangkutan;
b. menggunakan tanahanya;
c. menyerahkan bagian-bagian daripada tanah tersebut kepada pihak ketiga menurut persyaratan yang ditentukan oleh perusahaan pemegang hak tersebut, yang meliputi segi-segi peruntukan, penggunaan, jangka waktu dan keuangannya, dengan ketentuan bahwa pemberian hak atas tanah kepada pihak ketiga yang bersangkutan dilakukan oleh pejabat pejabat yang berwenang menurut Peraturan Menteri Dalam Negeri No. 6 Tahun 1972 tentang Pelimpahan Wewenang pemberian hak atas tanah.

Apabila ketentuan peraturan perundang-undangan sebagimana dipaparkan di atas dapat dilaksanakan sebagaimana seharusnya, maka disatu sisi tanah penguasaan pemerintah kota Malang yang disewa oleh pihak ketiga akan bermanfaat baik pemerintah Kota Malang sebagai sumber pendapatan asli daerah (PAD), sedangkan bagi masyarakat dapat memperoleh akses untuk memperoleh tanah persewaan yang relatif terjangkau terutama bagi golongan yang ekonomi lemah. 


\section{Rumusan Masalah}

Adapun rumusan masalah berkaitan dengan pengelolaan tanah penguasaan pemerintah Kota Malang adalah sebagai berikut:

1) Bagaimana historis/riwayat perolehan tanah Pemerintah Kota Malang yang disewa oleh pihak ketiga?

2) Hak atas tanah apakah yang sesuai menurut peraturan perundangundangan agar tanah penguasaan pemerintah kota Malang mempunyai kepatian hak dan kepastian hukum?

3) Apakah dasar hukum pengaturan sewa-menyewa dalam bentuk PERDA No. 4 Tahun 1997 telah sesuai dengan ketentuan peraturan perundang-undangan yang berlaku?

4) Manfaat apa yang akan diperoleh Pemerintah Kota Malang maupun masyarakat/Pihak Ketiga dengan adanya perjanjian sewa menyewa tanah tersebut?

5) Apakah hubungan sewa-menyewa antara pemerintah Kota Malang dengan Pihak Ketiga dimungkinkan untuk dilepaskan guna kepentingan Pihak Ketiga?

\section{Pembahasan}

\section{Historis perolehan tanah Pemerintah Kota Malang yang disewakan kepada pihak ketiga ?}

Telah dipaparkan dimuka bahwa historis atau riwayat perolehan tanah penguasaan pemerintah Kota Malang salah satu diantaranya karena adanya ketentuan Undang-undang yaitu:

\section{a. Pada masa pemerintahan Belanda}

Sebagaimana diketahui bahwa keberadaan pemerintah Kota Malang tidak dapat dipisahkan dengan pemerintahan yang mendahuluinya diawali pada saat pemerintahan Staat Gemeente (Kotapraja) Malang.

Pada masa pemerintahan Gemeente terdapat tanah-tanah yang dibeli oleh pemerintah pada waktu itu dan tanah-tanah tersebutmenjadi milik pemerintah Gemeente dengan satatus Tanah Hak Eigendom tertulis atas nama Staat Gemeente Malang. Disamping itu juga terdapat tanah-tanah yang dibeli tersebut belum sempat dibalik nama, tanahtanah tersebut ditemukan dalam Peta tercatat sebagai tanah G.G.

Tanah-tanah semacam ini tidak hanya ditemukan atas tanah yang dahulu dibeli oleh Staat Gemeente Malang, tetapi terdapat pula tanah yang dahulu dibeli oleh Tentara Kerajaan Belanda (KNIL) dan jawatan atau Kementerian lainnya seperti NIROM.

S. 1911 No.110 jo. 1940 No.430 memuat ketentuan-ketentuan umum tentang penguasaan terhadap "milik negara yang berupa benda- 
benda yang tidak bergerak“ dalam mana dicantumkan pokok pendirian, bahwa benda-benda yang tidak bergerak (dalam hal ini termasuk tanah) milik negara, ada dalam penguasaan Departemen (Kementerian), yang membeayai pemeliharaannya menurut anggaran belanja. Pada hakekatnya ketentuan itu adalah amat sempit, karena denngan demikian masih belum jelas, bagaimanakah halnya dengan penguasaan tanahtanah negara, yang tidak nyata-nyata dikuasai oleh suatu Departemen.

Dalam pada itu tentang penguasaan tanah-tanah "Vrijlandsdomein" itu ternyata, bahwa pemerintah Belanda dahulu berpegang pada pendirian bahwa:

a). tanah-tanah yang menjadi "Vrijlandsdomein" karena dibebaskan dari hak-hak milik Indonessia oleh suatu Departemen, dianggap ada di bawah penguasaan Departemen itu;

b). tanah-tanah "Vrijlandsdomein" yang penguasaannya tidak nyata-nyata diserahkan kepada suatu Departemen, dianggap ada dibawah penguasaan Departemen B.B.

\section{b. Pada masa Pemerintahan Jepang}

Setelah Belanda kalah perang melawan Jepang, maka Indonesia dijajah oleh pemerintah Jepang; pada masa penjajahan Jepang hampir tidak ada perubahan yang berarti dalam mengatur soal agraria; jika terdapat aturan-aturan soal agraria hanyalah mengenai istilah-istilah menurut bahasa Jepang. Sebagai contoh seperti peraturan yang dikeluarkan pada waktu itu yaitu Peraturan pangkal bagi larangan pemindahan atas benda-benda tetap (Osamu Seirei no. 2 Tahun 1942).

Yang dilakukan oleh Pemerintah pendudukan Jepang hanyalah mengobar-kobarkan peperangan melawan tentara sekutu untuk kemenangan bangsa Asia Timur Raya.

Dimasa pendudukan Jepang, keadaan dan suasana telah berubah sama sekali, maka untuk melancarkan usaha-usaha peperangan berbagai jawatan dari Pemerintah pendudukan Jepang diberi keleluasaan penuh untuk mengatur kepentingannya masing-masing. Akibatnya bahwa dalam urusan tanah Jawatan-Jawatan itu berbuat sekehendak sendiri dengan mengabaikan peraturan-peraturan yang ada.

Akhirnya banyak tanah-tanah Negara yang dengan begitu saja dipergunakan untuk keperluan yang menyimpang daripada tujuan yang telah ditentukan semula, atau yang dipindah-pindahkan dari tangan Jawatan yang satu ketangan Jawatan yang lain, dengan tidak melalui acara penyerahan dan penerimaan yang resmi melalui Berita acara. Banyak pula tanah-tanah Negara yang dibiarkan terlantar oleh JawatanJawatan yang tidak membutuhkannya lagi, selain itu sering juga pembelian-pembelian tanah penduduk yang tidak dilakukan menurut peraturan yang ada, kemudian tidak diketahui pula Jawatan mana yang menguasainya. 
Tindakan-tindakan semacam ini berlansung terus yang tidak menunjukan garis-garis kebijaksanaan yang sama dan diteruskan sesudah berakhirnya pendudukan Jepang, sehingga menimbulkan simpang siur dalam urusan penguasaan tanah Negara umumnya, yang tidak dapat diatasi dengan berpedoman pada peraturan dalam Staatsblad 1911 No.110 saja.

Selanjutnya setelah kemerdekaan Pemerintah mengeluarkan beberapa peraturan perundang-undangan sebagai berikut.

\section{c. Periode Kemerdekaan RI}

Setelah diproklamirkan kemerdekaan Negara kesatuan Republik Indonesia, maka tidak ada suatu kelompok masyarakat atau bangsa manapun yang tidak mempunyai aturan-aturan atau norma-norma tertentu yang mengatur tentang hak penguasaan atas tanah.

Bahwa suatu negara yang baru merdeka, sudah barang tentu belum dapat menyusun peraturan perundang-undangan yang lengkap untuk mengatur berbagai urusan termasuk urusan agraria; namun dalam pasal II Aturan Peralihan UUD-1945 meyatakan:

Semua badan-badan dan peraturan-peraturan yang ada sebelum diadakan yang baru tetap berlaku sepanjang tidak bertentangan dengan UUD. ini.

Oleh sebab itu selain peraturan agraria lama yang sebagian masih berlaku, dikeluarkan pula beberapa peraturan dan kebijakan pemerintah untuk mengatasi permasalahan tanah yang ada, dikeluarkan PP. No. 8 Tahun 1953 tentang Tanah Negara.

Beberapa istilah yang dicantumkan dalam peraturan tersebut antara lain menyebutkan:

a. Tanah Negara ialah tanah yang dikuasai penuh oleh Negara.

b. Daerah Swatantra ialah daerah yang diberi hak untuk mengurus rumah tangga sendiri, sebagai dimaksud dalam Pasal 131 Undang-undang Dasar Sementara RI.

Selanjutnya dalam Pasal 2 tentang ketentuan umum Peraturan Pemerintah tersebut menyatakan:

Kecuali jika penguasaan atas tanah Negara dengan Undangundang atau peraturan lain pada waktu berlakunya Peraturan Pemerintah ini, telah diserahkan kepada Kementerian, Jawatan atau Daerah Swatantra maka penguasaan atas tanah Negara ada pada Menteri Dalam Negeri.

Menurut Pasal 3 PP. No. 8 Tahun 1953 tersebut, Menteri Dalam Negeri berhak:

a. menyerahkan penguasaan itu kepada suatu Kementerian, Jawatan atau Daerah Swatantra untuk keperluan-keperluan 
bagi pelaksanaan kepentingannya sebagai dimaksud dalam Pasal 4;

b. mengawasi agar tanah negara tersebut dalam sub a dipergunakan sesuai dengan peruntukannya dan bertindak menurut ketentuan sebagai dimaksud dalam Pasal 8;

Selanjutnya menurut Pasal 4 angka 2 menyebutkan:

Penguasaan sebagai dimaksud dalam Pasal 3 ayat 1 sub a diserahkan kepada sesuatu Daerah Swatantra untuk menyelenggarakan kepentingan daerahnya, satu dan lain dengan mengindahkan ketentuan-ketentuan yang diadakan oleh Menteri Dalam Negeri.

Di dalam Pasal 8 menyatakan penguasaan tanah Negara itu dapat dicabut apabila:

a. penyerahan penguasaan itu ternyata keliru atau tidak tepat lagi;

b. luas tanah yang diserahkan ternyata sangat melebihi keperluannya;

c. tanah itu tidak dipelihara atau tidak dipergunakan sebagai mana mestinya.

Rumusan pasal yang tertuang di dalam peraturan tersebut di atas, dapat dipahami bahwa yang dimaksud dengan tanah Negara adalah tanah yang dikuasai penuh oleh Negara yang penguasaanya ada pada Menteri Dalam Negeri untuk diserahkan kepada Kementerian, Jawatan dan Daerah Swatantra, kemudian tanah-tanah tersebut sering pula disebut sebagai tanah penguasaan.

Dari paparan yang dijelaskan tersebut di atas bahwa tanah-tanah pada masa pemerintahan Belanda yang dibeli oleh sutau Kementerian, Jawatan menjadi milik Kementerian/ Jawatan yang membeayainya maka tanah-tanah Staat Gemeente beralih kepada Daerah Swatantra dalam hal ini salah satunya diantaranya adalah pemerintah Kota Malang.

2. Hak atas tanah apakah yang sesuai menurut peraturan perundangundangan agar tanah penguasaan pemerintah kota Malang mempunyai kepatian hak dan kepastian hukum?

Sebagaimana diketahui bahwa dengan dikeluarkannya UU. No. 5 Tahun 1960 tentang Peraturan Dasar Pokok-Pokok Agraria (UUPA), maka segala ketentuan yang berkaitan dengan persoalan tanah harus mengacu pada undang-undang tersebut termasuk peraturan pelaksanaannya.

Bahwa pemerintah kota Malang yang menguasai tanah penguasaan tersebut atas dasar penyerahan pengauasan dari Menteri Dalam Negeri sebagai dimaksud dalam pasal 3 PP. No. 8 Tahun 1953, seharusnya tanahtanah yang diserahkan kepada Daerah Swatntra/Pemerintah Kota yang disewakan kepada Pihak Ketiga tersebut dilekati dengan Hak Hak 
Penguasaan, selanjutnya berdasarkan ketentuan Peraturan Menteri Agraria No. 9 Tahun 1965 tanah tersebut dikonversi menjadi Hak Pengelolaan.

Tetapi tidak demikian halnya, bahwa hingga saat ini tanah penguasaan pemerintah kota Malang yang disewa oleh Pihak Ketiga belum dilekati sesuatu hak sesuai dengan ketentuan peraturan perundang-undangan yang berlaku.

Sehubungan dengan hal itu maka menimbulkan tidak adanya kepastian hak dan kepastian hukum.

\section{Atas dasar apa Pemerintah Kota Malang menyewakan tanah tersebut kepada pihak ketiga?}

Sebagaimana telah dipaparkan di muka, bahwa dasar hukum yang digunakan pemerintah Kota Malang menyewakan tanah tersebut kepada Pihak Ketiga adalah:

a. Pasal 35 UU. No. 22 Tahun 1948 dengan memperhatikan Keputusan Dewan Perwakilan Rakyat Daerah Sementara tanggal 31 Mei 1951 No. 27/D.P.R dan Keputusan Dewan Pemerintah Daerah tanggal 5-8-1954 No. 477/Pku

b. Pasal 14 (3) Penetapan Presiden Republik Indonesia No. 6/1959 dengan memperhatikan Keputusan Dewan Perwakilan Rakyat Daerah Sementara tanggal 30-9-1961 No. 1519/KD/61.

Tampaknya kedua peraturan perundang-undangan inilah yang dipakai dasar untuk menyewakan tanah kepada Pihak Ketiga, walaupun kemudian setelah tahun 1960 telah dikeluarkan UU. No. 5 Tahun 1960, jo Peraturan Menteri Agraria No. 9 tahun 1965 yang seharusnya dipakai sebagai dasar untuk menyerahkan bagian-bagian dari tanah Hak Pengelolaan kepada Pihak Ketiga.

Di dalam praktek bahwa yang dipakai sebagai dasar untuk menyewakan tanah penguasaan pemerintah Kota Malang kepada Pihak Ketiga adalah Peraturan Daerah No. 4 Tahun 1997 tentang Pemakaian Tempat-tempat Tertentu, walaupun di dalam konsiderans mengingat mencantumkan UU. No. 5 Tahun 1960, tetapi peraturan pelaksanaannya tidak mengikuti ketentuan peraturan perundang-undangan yang berlaku.

\section{Manfaat apa yang akan diperoleh Pemerintah Kota Malang maupun masyarakat/Pihak Ketiga dengan adanya perjanjian sewa menyewa tanah tersebut?}

Telah disinggung dimuka bahwa aset atau barang milik Daerah adalah merupakan unsur penting dalam rangka penyelenggaraan pemerintahan dan pembangunan.Dengan adanya tanah penguasaan pemerintah Kota yang disewa oleh Pihak Ketiga akan menghasilkan sumber pendapatan asli Daerah (PAD), maka akan bermanfaat bagi pemerintah Kota Malang.

Sedangkan manfaat yang diperoleh bagi Pihak Ketiga terutama mereka masyarakat golongan yang ekonomi lemah pada umumnya, agar dapat 
memperoleh akses berupa tanah untuk keperluan perumahan tempat tinggal dengan harga yang terjangkau, oleh karena persewaan tanah yang dilakukan oleh pemerintah Kota Malang bukan merupakan perusahaan tanah yang bertujuan untuk memperoleh keuntungan, tetapi pemerintah/pemerintah daerah mempunyai misi untuk mensejahterakan rakyatnya.Dengan demikian apa bila misi yang diemban oleh pemerintah Kota Malang agar dapat terwujudnya mereka masyarakat golongan ekonomi lemah untuk memperoleh akses guna mendapatkan tanah persewaan, maka berangsurangsur akan dirasakan pula rasa keadilan yang sangat didambakan oleh masyarakat.

Sehubungan dengan hal itu tampaknya pengadaan tanah untuk keperluan perumahan terutama bagi masyarakat yang menghuni daerah aliran sungai Brantas (DAS Brantas) dan daerah-daerah rawan bencana lainnya perlu mendapatkan perhatian untuk memperoleh kesempatan mendapatkan tanah persewaan atas tanah penguasaan pemerintah Kota Malang.

Suryawasita dalam Banawiratma menyatakan:

Dalam pengertian keadilan itu dibedakan antara keadilan individual dan keadilan sosial. Hukum memandang penting keduanya, namun kaitannya dengan kerawanan yang sering timbul dalam masyarakat, keadilan sosial menjadi fokus utama. Keadilan sosial pelaksanaannya tergantung pada struktur masyarakat, dan tanggung jawab keadilan sosial menjadi tanggung jawab semua pihak ${ }^{4}$

Lebih lanjut mengenai pilihan yang paling tepat dari prinsip keadilan (keadilan atas dasar hak, keadilan atas dasar jasa dan keadilan atas dasar kebutuhan).

Suryawasita lebih senderung untuk memberikan tempat kepada keadilan atas dasar kebutuhan, mengingat secara keselutuhan lebih banyak masyarakat yang bernasib kurang menguntungkan. ${ }^{5}$

\section{Apakah hubungan sewa-menyewa antara pemerintah Kota Malang dengan Pihak Ketiga dimungkinkan untuk dilepaskan guna kepentingan Pihak Ketiga?}

Hubungan sewa-menyewa antara pemerintah Kota Malang dengan Pihak Ketiga adalah didasarkan adanya kesepakatan para pihak.

Pengalaman menunjukkan bahwa tanah penguasaan pemerintah Kota Malang yang disewa oleh Pihak Ketiga dapat dilepaskan kepada Pihak Ketiga hal ini juga tidak terdapat aturan yang mengatur tentang larangan tanah persewaan dimaksud.

\footnotetext{
${ }^{4}$ Bumi Bhakti Adhiguna-Jakarta 1987: 13.

${ }^{5}$ Bumi Bhakti Adhiguna-Jakarta 1989: 26-27.
} 
Agar tersedianya tanah penguasaan pemerintah Kota Malang yang disewa oleh Pihak Ketiga dapat terjamin kelangsungannya, maka pelepasan tanah tersebut seyogianya dilakukan secara selektif, artinya bahwa Pihak Ketiga yang menyewa tanah penguasaan pemerintah Kota Malang benarbenar Pihak Ketiga yang belum mempunyai tanah/rumah sendiri.

Selain itu perlu diperhatikan bahwa hasil uang pemasukan sebagi pelepasan tanah penguasaan tersebut harus dibelanjakan kembali dalam bentuk tanah, apabila uang pemasukan dari pelepasan tersebut belum mencukupi harus dihimpun dalam Kas Daerah sebagai mata anggaran untuk pengadaan tanah guna tanah persewaan yang dikelola oleh Dinas Perumahan Pemerintah Kota Malang.

\section{Penutup}

Dari latar belakang, hasil temuan, dan pembahasan halaman-halaman sebelumnya, maka dapat kami simpulkan sebagai berikut:

1. Hasil kajian tim peneliti menunjukkan secara historis atau riwayat perolehan tanah penguasaan pemerintah Kota Malang banyak ragamnya bisa terjadi karena ketentuan undang-undang, pembelian atau pembebasan tanah, penyerahan dari pihak lain yang sah, termasuk pula karena adanya perubahan status Desa yang berubah menjadi Kelurahan.

2. Pemerintah Kota Malang belum melaksanakan ketentuan peraturan hukum tanah khususnya yang berkaitan dengan tanah-tanah penguasaan pemerintah Kota Malang yang seharusnya dilekati dengan Hak Pengelolaan, tetapi hingga saat ini belum dilaksakan, sehingga tidak terjamin adanya kepastian hak dan kepastian hukumnya.

3. Diperlukan upaya secara sungguh-sungguh dan berkelanjutan untuk melakukan pendataan, inventarisasi serta pencatatan secara periodik aset pemerintah daerah, dengan berkoordinasi dengan pemangku kepentingan yang terkait 